\title{
Pengembangan Media Pembelajaran Mengunakan Aplikasi Construct 2 Pada Materi Aljabar Kelas VII
}

\author{
Titon Agung Saputro ${ }^{1}$, Kriswandani ${ }^{2}$, Novisita Ratu ${ }^{3}$ \\ ${ }^{1,2,3}$ Pendidikan Matematika,Universitas Kristen Satya Wacana, \\ 1202014027@student.uksw.edu, , ${ }^{2}$ kriswandani@staff.uksw.edu, ${ }^{3}$ novisita.ratu@staff.uksw.edu
}

\section{INFO ARTIKEL}

Riwayat Artikel:

Diterima: 07-02-2018

Disetujui: 01-03-2018

\section{Kata Kunci:}

Aljabar

Platform

Game edukasi

Media pembelajaran

\begin{abstract}
ABSTRAK
Abstrak: Jenis penelitian ini adalah penelitian dan pengembangan (Research and Development) dengan tujuan mengembangkan media pembelajaran game edukasi berbasis platform game untuk siswa kelas VII SMP. Penelitan ini menggunakan desain penelitian Borg \& Gall yang terdiri dari sepuluh langkah. Teknik pengumpulan data terdiri dari observasi, kuesioner dan tes. Hasil dari penelitian pengembangan ini adalah aplikasi game platform dengan materi aljabar. Dampak dari media pembelajaran game edukasi platform game adalah media pembelajaran berpengaruh terhadap hasil belajar siswa. Hal ini berdasarkan pada uji MannWhitney dengan nilai signifikan $0,000<0,05$ yang berarti terdapat perbedaan rerata sebelum dan sesudah pemberian media pembelajaran game edukasi berbasis platform game atau terdapat pengaruh game edukasi platform game pada materi aljabar terhadap hasil belajar siswa. Selain itu, nilai N-Gain yang diperoleh adalah 0,49 yang berarti terjadi peningkatan sedang terhadap hasil belajar siswa.
\end{abstract}

\begin{abstract}
The type of this research is research and development with the aim of developing game-based learning media game of platform game for VII class student of SMP using application of Construt 2. This research use Borg \& Gall research design which consist of ten stages. Data collection techniques consist of observations, questionnaires and tests. The results of this development research is a platform game application with algebraic material. The impact of instructional media game game education game is the media influence on student learning outcomes. This is based on the Mann-Whitney test with a significance value of $0.000<0.05$ which means there is an average difference before and after the delivery of learning media game-based platform learning or the influence of algebraic game education game. material in algebra on student learning outcomes. In addition, the $N$-Gain value obtained is 0.49 which means a moderate increase in student learning outcomes.
\end{abstract}

\section{A. PENDAHULUAN}

Kemajuan ilmu pengetahuan dan teknologi saat ini berkembang sangat pesat. Salah satu teknologi yang saat ini sedang berkembang dan cukup banyak diminati oleh masyarakat ialah komputer. Komputer sudah banyak digunakan di sekolah- sekolah mulai dari Sekolah Dasar hingga Sekolah Menengah Atas karena memiliki banyak manfaat di bidang pendidikan. Salah satu manfaat komputer di bidang pendidikan adalah sebagai media pembelajaran. Menurut Schramm dalam Sudrajat (2008), media pembelajaran merupakan teknologi pembawa pesan yang dapat dimanfaatkan untuk keperluan pembelajaran. Pendapat tersebut didukung oleh Miarso (2004) yang berpendapat bahwa media pembelajaran adalah segala sesuatu yang digunakan untuk menyalurkan pesan serta dapat merangsang pikiran, perasaan, perhatian dan kemauan siswa sehingga dapat mendorong terjadinya proses belajar. Oleh karena itu, media pembelajaran dapat membantu siswa dalam mempelajarai materi pembelajaran khususnya pada pembelajaran matematika.

Matematika merupakan suatu ilmu yang menggunakan nalar sehingga matematika dianggap sesuatu yang sulit untuk dipelajari. Media pembelajaran komputer diharapkan dapat menunjang proses pembelajaran matematika dan dapat membantu menciptakan pembelajaran yang bermakna. Menurut Samani (2007), pembelajaran 
bermakna (meaningful learning) merupakan suatu proses mengaitkan informasi baru pada konsepkonsep relevan yang terdapat dalam struktur kognitif seseorang. Hal tersebut menunjukkan bahwa proses belajar tidak sekedar menghafal konsep saja melainkan dapat menghubungkan konsep tersebut untuk menghasilkan pemahaman yang utuh sehingga apa yang dipelajari dapat dipahami dengan baik dan tidak mudah dilupakan.

Di sisi lain, media pembelajaran komputer belum dimanfaatkan secara optimal di dalam proses belajar mengajar. Berdasarkan hasil observasi dan wawancara yang dilakukan di salah satu SMP di Salatiga menunjukkan bahwa penggunaan komputer di laboratorium komputer belum dimanfaatkan sebagai media pembelajaran termasuk pada pelajaran matematika. Selain itu, guru menyampaikan pembelajaran seperti biasa, sehingga siswa kurang tertarik dan kurang bersemangat dalam mengikuti pelajaran matematika.

Berdasarkan uraian tersebut, perlu adanya pengembangan media pembelajaran komputer salah satunya yaitu dengan membuat aplikasi permainan yang dapat gunakan melalui komputer. Aplikasi pembuat game atau biasa disebut game engine sudah beragam salah satunya adalah dengan menggunakan Construct 2. Construct 2 adalah game engine yang mudah digunakan untuk pemula. Sholihin dan Farouq (2016) menyatakan bahwa Construct 2 adalah software yang canggih fitur HTML5 Game Creator dirancang khusus untuk game 2D (platform game).

Construct 2 dapat membuat media pembelajaran yang berbasis game seperti yang pernah dilakukan oleh Sholihin (2012) menghasilkan media berbasis permainan. Pengembangan media mengunakan Construct 2 juga dilakukan dalam pembelajaran matematika. Hal ini dapat dilihat pada penelitian Adiwijaya (2015) yang menghasilkan game platform untuk belajar exponensial berbasis android menggunakan Construct 2. Pengembangan yang sama dilakukan oleh Thomas (2014) yang menghasilkan game untuk titik kordinat. Oleh karena itu dapat disimpulkan bahwa pengunaan Construct 2 dapat dilakukan untuk mengembangkan media pembelajaran matematika.

Berdasarkan latar belakang dan permasalahan di atas maka dapat dirumuskan tujuan dari penelitian ini adalah untuk mengembangkan media pembelajaran game edukasi berbasis platform game pada materi aljabar bagi siswa kelas VII SMP. Tujuan lain dari penelitian ini adalah untuk mengetahui dampak pemberian media pembelajaran game edukasi berbasis platform game pada materi aljabar terhadap hasil belajar siswa kelas VII SMP.

\section{B. METODE PENELITIAN}

Jenis penelitian ini adalah penelitian dan pengembangan, dimana produk dari pengembangan ini adalah media pembelajaran game edukasi berbasis platform game. Dalam menghasilkan produk, digunakan penelitian yang bersifat analisis kebutuhan dan untuk menguji keefektifan produk supaya dapat berfungsi di masyarakat luas. Subjek penelitian adalah siswa kelas VII SMP Pangudi Luhur Salatiga yang berjumlah 29 siswa. Pengembangan game edukasi berbasis platform game pada materi aljabar menggunakan langkah-langkah model Borg \& Gall yang meliputi:

\section{Research and Information Collecting}

Langkah pertama ini dilakukan untuk mengetahui perlunya pengembangan media pembelajaran game edukasi berbasis platform game pada materi aljabar. Pengumpulan informasi dan penelitian dalam tahap ini adalah:

a. Studi Lapangan

Berdasarkan pengamatan fasilitas belajar di SMP Pangudi Luhur Salatiga, terdapat 1 ruang laboratorium komputer yang dimiliki oleh sekolah. Laboratorium tersebut hanya digunakan saat mata pelajaran Teknik Informasi dan Komunikasi (TIK). Dalam hal ini, peneliti menggunakan laboratorium komputer yang ada, dengan jumlah komputer sebanyak 30 unit. Berdasarkan hasil wawancara peneliti dengan guru mata pelajaran matematika, pembelajaran matematika di dalam kelas dan menggunakan alat peraga untuk materi tertentu, misal materi bangun ruang. Guru tidak menggunakan media pembelajaran selain media papan tulis dan buku siswa.

b. Studi Pustaka

Studi pustaka dilakukan untuk memperoleh informasi berkenaan dengan game edukasi berbasis platform game yang akan dikembangkan.

\section{Planning}

Pada tahap ini peneliti menentukan materi yang akan dikembangkan dalam game edukasi sesuai dengan silabus matematika kelas VII SMP dan berdasarkan hasil pembicaraan dengan guru matematika. Materi yang menjadi bahan untuk game edukasi adalah Aljabar. Setelah menetapkan materi 
yang akan dijadikan konten dalam aplikasi game edukasi, peneliti menentukan gambaran umum mengenai game edukasi yang akan dikembangkan. Konten materi yang ditampilkan pada aplikasi game edukasi disesuaikan dengan kompetensi dasar yang telah ditetapkan pada Kurikulum. Penyajian materi diatur secara urut berdasarkan pada urutan proses pembelajaran.

\section{Develop Preliminary Form of Product}

Langkah ini meliputi kegiatan memodifikasi materi aljabar untuk selanjutnya dimasukkan ke dalam game edukasi sebagai konten dari game itu sendiri. Pembuatan game edukasi menggunakan software Construct 2. Pengadaan bahan ajar disesuaikan dengan tujuan pembelajaran spesifik yang telah dirumuskan oleh peneliti pada langkah planning. Langkah-langkah dalam membuat aplikasi game edukasi berbasis platform game pada materi aljabar antara lain:

a. Menentukan storyline

Peneliti membuat aplikasi game edukasi dengan judul permainan "Calm Gero" dengan Gero sebagai tokoh utama dalam permainan. Cerita dalam permainan ini adalah Gero diculik oleh sekumpulan makluk asing dari planel lain. Gero harus melarikan diri dari makluk asing tersebut, Gero harus mengambil kunci untuk membuka setiap pintu yang ada. Kunci tersebut berisi materi aljabar. Terdapat juga soal yang diutarakan dalam permainan ini yaitu soal-soal tentang aljabar.

b. Membuat tokoh-tokoh dalam permainan

Peneliti membuat tokoh-tokoh dalam permainan menggunakan karakter yang dibuat oleh RedFoc. Tokoh utama dari game ini adalah Gero, alien lucu. Tokoh musuh dalam game ini adalah beberapa alien jahat berwarna hitam yang terdiri dari 3 bentuk yang berbeda.

c. Membuat peraturan permainan

Peneliti menyusun beberapa peraturan dalam permainan sehingga dapat memberikan tantangan bagi siswa untuk dapat menyelesaikan soal-soal dengan cepat dan tepat. Peraturan-peraturan dalam permainan antara lain:

1) Jika pemain tidak mengambil semua kunci yang ada dalam setiap level maka pemain tidak bisa maju dalam level selanjutnya.

2) Setiap soal yang ada akan memberikan tambahan 20 poin jika dapat menjawab dengan benar, jika pemain salah menjawab maka poin pemain akan dikurangi 5 poin dan jika pemain menutup soal akan dikurangi 15 poin.

3) Pemain diberi 3 Health, jika terkena musuh maka Health yang dimiliki pemain akan berkurang. Apabila Health yang dimiliki telah habis permainan akan berakhir (game over) dan akan mengulangi lagi dari awal level.

\section{d. Membuat game}

Pada tahai ini, peneliti mengunakan aplikasi Construct 2 untuk membuat produk aplikasi game edukasi dengan materi aljabar. Proses pembuatan game terdiri dari pembuatan map (peta), penyusunan Event atau script, pemilihan musik latar, dan memasukkan konten materi aljabar ke dalam game. Komponen-komponen utama dalam aplikasi ini adalah:

\section{1) Menu Utama}

Menu utama dalam aplikasi ini terdiri dari pilihan Mulai untuk memulai permainan, simbol "i" yang berisi informasi cara memainkan dan aturan permainan.

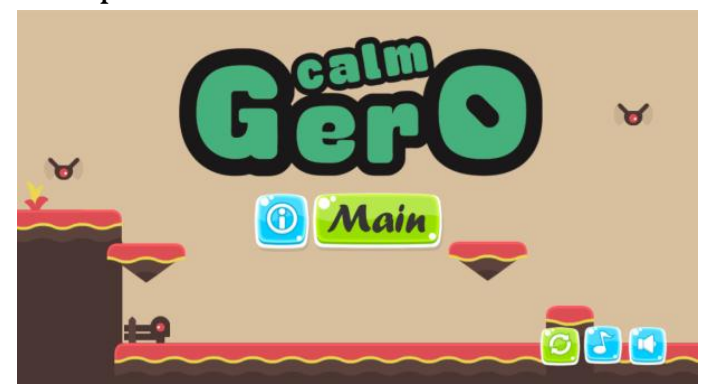

Gambar 1. Menu Utama

\section{2) Peraturan Permainan}

Peraturan permainan diberikan agar permainan mempunyai faktor penentu menang atau kalah bagi pemainnya. Peraturan permainan diberikan di awal permainan.

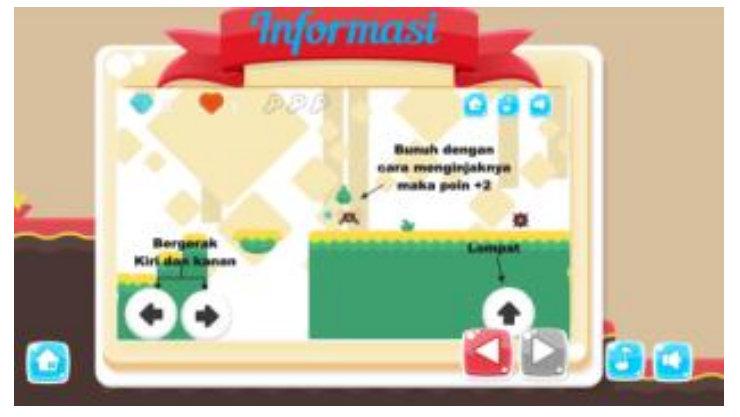




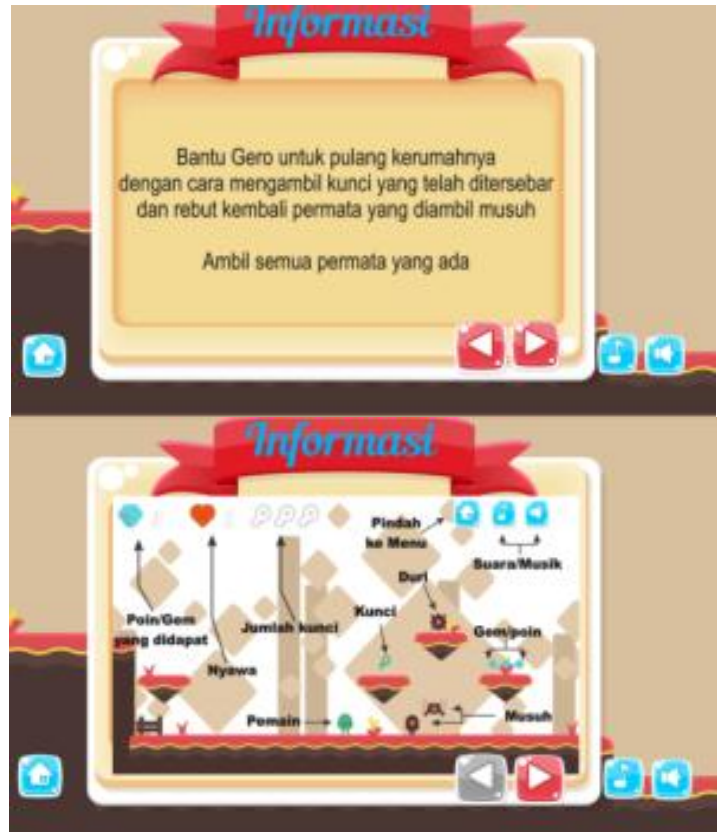

Gambar 2. Peraturan Permainan

\section{3) Materi dan Latihan Soal}

Materi yang ditampilkan dalam aplikasi game edukasi berbasis platform game adalah aljabar yang telah disesuaikan dengan Kurikulum 2013. Penyajian materi dalam setiap level secara urut dimulai dari bentuk aljabar, komponen aljabar, suku-suku dalam aljabar, dan operasi aljabar. Materi disusun berdasarkan silabus matematika kelas VII Kurikulum 2013 dan memuat pembelajaran yang kontekstual. Beberapa gambar dimuat sebagai ilustrasi contoh soal.

Contoh soal diberikan pada setiap level sehingga siswa lebih memahami materi aljabar dengan menyelesaikan misi dalam game. Setelah diberikan contoh soal, pemain harus mengerjakan latihan soal yang disediakan pada setiap level. Benar atau salah dalam menjawab soal mendapatkan hadiah atau hukuman berupa penambahan atau pengurangan poin pemain.

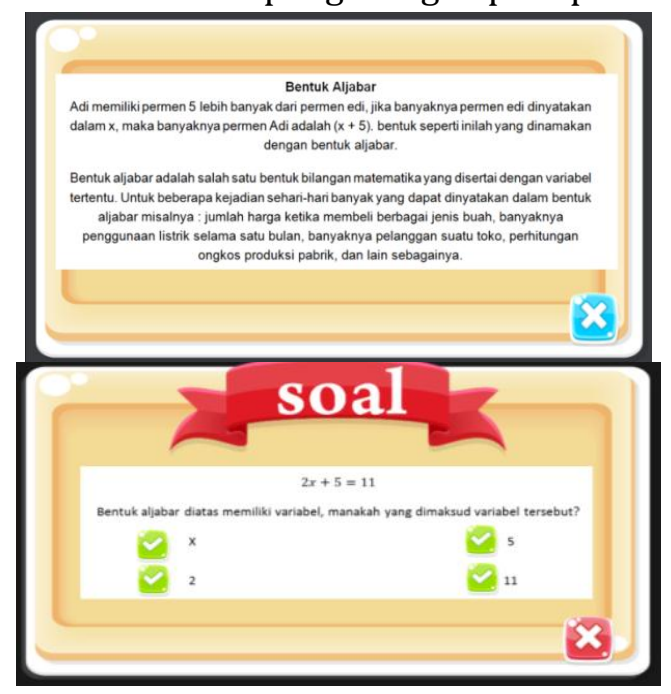

Gambar 3. Materi dan Pemberian Latihan Soal

\section{4) Soal Evaluasi}

Soal evaluasi pada game terdapat pada akhir level, yaitu saat pemain dekat dengan pintu rumahnya. Dalam perjalanan terakhir mendapat kotak berisi 10 buah soal tersebut yang berhubungan dengan materi aljabar sebelumnya. Tujuan pengadaan evaluasi adalah agar siswa dapat menerapkan apa yang telah dipelajari dari level sebelumnya.

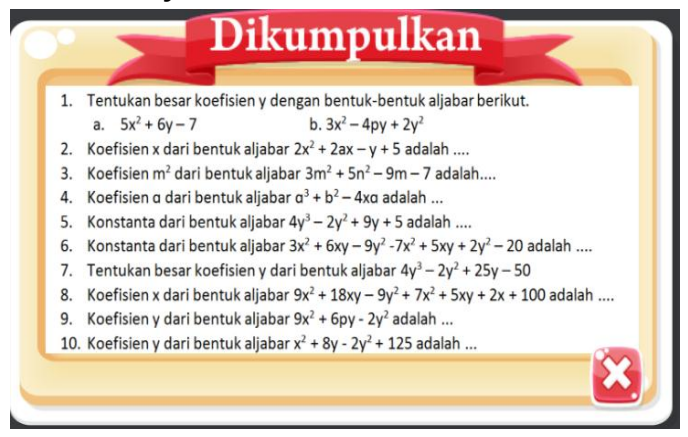

Gambar 4. Evaluasi Akhir Dalam Permainan

\section{Preliminary Field Testing}

Tahap preliminary field testing dilakukan untuk menguji validitas dan realibilitas dari produk yang dikembangkan. Validasi ini diperlukan untuk memeriksa apakah produk yang dikembangkan sudah layak untuk dipakai. Validasi dilakukan oleh dua validator, yaitu validator ahli media dan validator ahli materi.

\section{a. Data Hasil Validasi Ahli Media}

Ahli media menitikberatkan penilaian media terhadap aspek tampilan, audio, dan aspek pemrograman. Ahli media yang menjadi validator produk adalah Aldian Umbu Tamu Ama, S.Si,MCS. Beliau merupakan dosen dari Fakultas Teknologi dan Ilmu Komunikasi Universitas Kristen Satya wacana.

Berdasarkan hasil validasi media oleh ahli media diperoleh presentase 85\% dengan kategori sangat layak sehingga dapat diinterpretasikan bahwa game edukasi berbasis platform game pada materi aljabar sangat layak digunakan sebagai media pembelajaran.

b. Data Hasil Validasi Ahli Materi

Ahli materi menitikberatkan penilaian media terhadap aspek isi/materi dan aspek pembelajaran dan kebahasaan. Ahli materi yang menjadi validator produk adalah Tri Wahyuni Esti, S.pd. Beliau adalah guru mata pelajaran matematika SMP Negeri 7 Salatiga.

Berdasarkan hasil validasi media oleh ahli materi diperoleh presentase $91,67 \%$ dengan 
kategori sangat layak sehingga dapat diinterpretasikan bahwa game edukasi berbasis platform game pada materi Aljabarsangat layak digunakan sebagai media pembelajaran.

\section{Main Product Revision}

Setelah produk diuji oleh ahli media dan ahli materi, kritik dan saran dari valiadator menjadi acuan dalam perbaikan dari aplikasi game edukasi. Saran-saran perbaikan dan tindak lanjut revisi dari produk media pembelajaran game edukasi adalah sebagai berikut.

a. Jarak setiap level terlalu panjang

Berdasarkan pendapat ahli media, percakapan antar tokoh terlalu panjang sehingga dikhawatirkan akan membuat siswa kesusahan dalam menyelesaikan permainan dan latihan soal. Oleh karena itu, peneliti mempersingkat jarak map pada setiap level.

b. Materi dimunculkan pada tempat yang berbeda

Materi pada produk awal hanya muncul di bagian bawah layar saja. Perbaikan pada kotak materi yang selalu muncul di bawah digantikan dengan kotak dialog antar tokoh yang muncul di posisi yang berbeda (ditengah) sehingga pandangan pengguna game tidak hanya ke bagian bawah layar saja.

c. Petunjuk permainan harus lebih jelas

Petunjuk permainan pada produk awal tidak diberikan dengan jelas, sehingga dilakukan revisi kedua dengan memberikan petunjuk permainan di awal permainan.

d. Skenario pada game harus lebih matang

Skenario pada game harus matang, dimana dalam cerita harus ada penentu akhir cerita. Dalam permainan ini penulis membuat alur cerita dimana tokoh utama harus mengambil semua kunci dalam setiap level kemudian di akhir cerita tokoh utama harus menjawab soal evaluasi.

e. Fasilitas game ditambahkan top score, game over, dan map preview

Sebuah permainan menjadi menantang apabila diberi variabel-variabel penentu kemenangan dalam permainan. Validator media menyarankan untuk menambahkan fasilitas top score agar setiap siwa yang memainkan permainan dapat membandingkan skor akhir yang dimiliki. Tetapi, penambahan tampilan top score tidak dapat dilakukan karena membutuhkan web servers, php, mysql dan pengubahan plugin javascript file. Revisi untuk penambahan map preview tidak dapat dilakukan karena belum tersedia plug-in untuk menyematkan peta pratinjau dalam permainan (game screen). Sebagai gantinya, ukuran map dipersempit dan diberi arah jalan sehingga pemain tidak tersesat ke daerah lain. Selain itu, ditambahkan arah jalan pada map agar permain tidak tersesat ke daerah lain.

f. Teks percakapan jangan sampai menutupi gambar

Pada produk awal game edukasi, terdapat suatu kondisi dimana kotak teks yang memunculkan dialog antartokoh menutupi gambar ilustrasi. Oleh karena itu dilakukan pengubahan dengan memindah posisi munculnya kotak teks sehingga tidak menuutpi gambar ilustrasi.

Setelah dilakukan perbaikan terhadap produk awal game edukasi, penelitian dilanjutkan dengan uji coba media skala kecil.

\section{Main Field Testing}

Pada tahap main field testing atau uji coba skala kecil, data hasil uji coba skala kecil didapatkan dari angket penilaian yang diisi oleh objek uji coba yaitu 5 siswa kelas VII yang diambil secara acak. Pengambilan data ini bertujuan untuk mengetahui penilaian dari siswa dalam skala kecil mengenai kualitas dari aplikasi game edukasi yang telah dikembangkan sebagai media pembelajaran sebelum diuji cobakan dalam skala besar.

Berdasarkan hasil uji coba media skala kecil diperoleh presentase 95,5\% dengan kategori sangat layak dan siswa dapat memahami serta mengoperasikan aplikasi pembelajaran yang diberikan sehingga dapat diinterpretasikan bahwa game edukasi berbasis platform game pada materi aljabar sangat layak digunakan sebagai media pembelajaran.

\section{Operational Product Revision}

Setelah melaksanakan uji coba utama terhadap 5 siswa, langkah selanjutnya adalah merevisi kembali game edukasi berdasarkan hasil dari pengisian angket oleh siswa sehingga game edukasi dapat diuji kembali pada uji coba operasional / skala besar.

Berdasarkan kegiatan siswa dalam mengoperasikan game edukasi maka tidak ada revisi serta berdasarkan pengisian angket dan lembar pendapat siswa pada uji coba skala kecil, tidak ada saran perubahan terhadap produk media pembelajaran. Oleh karena itu media pembelajaran 
dapat dilanjutkan dengan uji coba skala besar. Uji coba skala besar ini berupa pemberian media pembelajaran ke 1 kelas yang dipilih yakni kelas VIIA SMP Negeri Pangudi Luhur Salatiga.

\section{Operational Field Testing}

Produk yang telah direvisi setelah uji coba skala kecil selanjutnya diujicobakan kepada siswa skala besar untuk mengetahui penilaian dari siswa mengenai kualitas dari aplikasi game edukasi yang telah dikembangkan sebagai media pembelajaran setelah diujicobakan dalam skala kecil untuk mendapatkan hasil yang lebih akurat. Data hasil uji coba skala besar didapatkan dari pengisian angket oleh 29 siswa dari kelas VIIA SMP Pangudi Luhur Salatiga.

Berdasarkan hasil uji coba media skala besar diperoleh presentase $84,44 \%$ dengan kategori sangat layak sehingga dapat diinterpretasikan bahwa game edukasi berbasis platform game pada materi Aljabar sangat layak digunakan sebagai media pembelajaran.

\section{Final Product $R$ evision}

Setelah melaksanakan uji coba skala besar, game edukasi aljabar direvisi kembali. Pada tahap ini tidak ada perubahan terhadap produk aplikasi game edukasi. Produk akhir pada pengembangan ini adalah media pembelajaran game edukasi berbasis platform game pada materi aljabar yang telah diujicobakan dan mendapat tanggapan bahwa media ini baik dan layak dijadikan media pembelajaran di kelas.

\section{Dissemination and Implementation}

Pada tahap ini, aplikasi game edukasi disseminasi melalui seminar internasional teknologi pendidikan sehingga dapat disebarluaskan dan dapat diterapkan di berbagai tempat. Selain itu, game edukasi ini dipublikasikan online.

\section{HASIL DAN PEMBAHASAN}

Hasil penelitian ini berupa dampak pemberian media pembelajaran game edukasi terhadap hasil belajar siswa. Pemberian tes ini dilakukan sebelum dan sesudah pemberian media pembelajaran. Selain itu juga dipilih 2 kelas yakni kelas eksperimen yakni kelas yang diberi media pembelajaran game edukasi serta kelas kontrol yakni kelas yang diberi media tayangan presentasi (ppt). Adapun hasilnya adalah sebagai berikut

\section{Deskripsi Hasil Pengolahan Data}

Berdasarkan hasil pengolahan nilai pretest dan posttest dari kedua kelas, diketahui bahwa di kelas eksperimen, nilai rata-rata pretest $(71,55)$ lebih rendah dibandingkan dengan nilai rata-rata posttest $(85,51)$ dimana peningkatan nilainya cukup signifikan yakni hampir 15 point. Hal serupa di kelas kontrol dimana nilai rata-rata pretest $(71,42)$ lebih rendah dibandingkan dengan nilai rata-rata posttest $(80,17)$ dimana peningkatan nilainya juga meningkat yakni sekitar 10 point. Jika dibandingkan nilai ratarata pretest antara kelas eksperimen dan kelas kontrol maka nilai rerata kelas eksperimen lebih baik daripada nilai rerata kelas kontrol dimana selisihnya sangat kecil. Jika dibandingkan nilai rata-rata postest antara kelas eksperimen dan kelas kontrol maka nilai rerata kelas eksperimen lebih baik daripada nilai rerata kelas kontrol dimana selisihnya cukup banyak. Untuk mengetahui perbedaan kedua nilai rerata dari kedua kelas maka dapat digunakan uji beda rerata dan untuk peningkatannya dengan menggunakan $\mathrm{N}$ Gain.

\section{Analisis Data}

Analisis uji kesamaan rata-rata pretest bertujuan untuk menunjukkan bahwa tidak terdapat perbedaan yang signifikan terhadap kemampuan awal antara kelompok eksperimen dan kelompok kontrol. Sebelum melakukan uji keseimbangan data maka dilakukan uji normalitas dan homogenitas data.

\section{a. Uji Normalitas}

Uji normalitas dilakukan pada nilai kelas eksperimen dan kelas kontrol. Uji normalitas dilakukan dengan uji Shapiro-Wilk dengan taraf signifikan 0,05.

TABEL 1

NORMALITAS NILAI PRETEST DAN POSTTEST DARI KEDUA KELAS

\begin{tabular}{|c|c|c|}
\hline & \multicolumn{2}{|c|}{ Shapiro-Wilk } \\
\hline & Statistic & df Sig. \\
\hline Nilai Pretest Kelas Eksperimen & .882 & 28.004 \\
\hline Nilai Postest Kelas Eksperimen & .908 & 28.018 \\
\hline Nilai Pretest Kelas Kontrol & .881 & 28.004 \\
\hline Nilai Postest Kelas Kontrol & .922 & 28.038 \\
\hline
\end{tabular}

Berdasarkan Tabel 1, nilai signifikan nilai pretest untuk kelas eksperimen adalah 0,004 dan kelas kontrol adalah 0,004. Begitu juga dengan nilai posttest untuk kelas eksperimen adalah 0,018 dan nilai signifikansi yang diperoleh kelas kontrol adalah 0,038. Tampaklah bahwa nilai signifikansi dari uji normalitas pretest dan posttest dari kedua kelompok data lebih kecil daripada 0,05 sehingga dapat diartikan bahwa data pretest dan posttest 
untuk masing-masing kedua kelas tidak berdistribusi normal. Oleh karena itu, dilakukan uji Mann-Whitney.

\section{b. Uji Mann-Whitney}

Pengujian uji beda rerata dilakukan terhadap nilai pretest dan posttest kelas eksperimen dan kontrol, dan nilai sebelum dan sesudah pemberian media pembelajaran game edukasi. Hasil dari uji Mann-Whitney adalah sebagai berikut.

1) Uji keseimbangan kelas eksperimen dan kelas kontrol

Pengujian keseimbangan dua kelas ini adalah pengujian nilai pretest kelas eksperimen dan kelas kontrol. Hasil pengujiannya adalah sebagai berikut.

TABEL 2

UJI MANN-WHITNEY NILAI PRETEST

KELAS ESKPERIMEN DAN KONTROL

\begin{tabular}{cc}
\hline & $\begin{array}{c}\text { Nilai Pretest Kelas Kontrol dan } \\
\text { Eksperimen }\end{array}$ \\
\hline Mann-Whitney U & 399.500 \\
Wilcoxon W & 834.500 \\
Z & -.110 \\
Asymp. Sig. (2- & .913 \\
tailed) & \\
\hline
\end{tabular}

Berdasarkan hasil uji Mann-Whitney diperoleh nilai signifikansi sebesar 0,913>0,05 sehingga dapat disimpulkan bahwa tidak terdapat perbedaan nilai rerata pretest antara kelas eksperimen dan kelas kontrol. Oleh karena itu dapat disimpulkan bahwa antara kelas eksperimen dan kelas kontrol seimbang

2) Uji beda rerata antara kelas eksperimen dan kelas kontrol

Pengujian beda rerata dua kelas ini adalah pengujian nilai posttest kelas eksperimen dan kelas kontrol. Hasil pengujiannya adalah sebagai berikut.

TABEL 3

UJI MANN-WHITNEY NILAI POSTTEST KELAS EKSPERIMEN DAN KONTROL

\begin{tabular}{cc}
\hline & $\begin{array}{c}\text { Nilai Postest Kelas Kontrol } \\
\text { dan Eksperimen }\end{array}$ \\
\hline Mann-Whitney U & 108.500 \\
Wilcoxon W & 514.500 \\
Z & -4.846 \\
Asymp. Sig. (2- & .000 \\
tailed) & \\
\hline
\end{tabular}

Berdasarkan hasil uji Mann-Whitney diperoleh nilai signifikansi sebesar 0,000 $<0,05$ sehingga dapat disimpulkan bahwa terdapat perbedaan nilai rerata posttest antara kelas eksperimen dan kelas kontrol. Oleh karena itu dapat disimpulkan bahwa terdapat pengaruh media pembelajaran game edukasi terhadap hasil belajar siswa.

3) Uji beda rerata nilai sebelum dan sesudah diberi media pembelajaran game edukasi

Uji beda rerata ini dilakukan pada nilai pretest dan posttest kelas eksperimen untuk mengetahui adanya perbedaan rerata sebelum dan sesudah diberi media pembelajaran game edukasi. Hasil pengujiannya adalah sebagai berikut.

TABEL 4

UJI MANN-WHITNEY NILAI KELAS EKSPERIMEN

\begin{tabular}{cc}
\hline & $\begin{array}{c}\text { Nilai Pretest dan Postest } \\
\text { Kelas Eksperimen }\end{array}$ \\
\hline Mann-Whitney U & 42.000 \\
Wilcoxon W & 477.000 \\
Z & -5.966 \\
Asymp. Sig. (2- & .000 \\
tailed) & \\
\hline Berdasarkan
\end{tabular}

Berdasarkan hasil uji Mann Whitney diperoleh nilai signifikansi sebesar 0,000 $<0,05$ sehingga dapat disimpulkan bahwa terdapat perbedaan nilai rerata pretest dan posttest kelas eksperimen. Oleh karena itu dapat disimpulkan bahwa terdapat perbedaan nilai rerata antara kelas pretest dan posttest pada kelas eksperimen dimana nilai rerata pretest sebelum diberi media pembelajaran game edukasi lebih rendah dibandingkan nilai rerata posttest setelah diberi media pembelajaran game edukasi.

TABEL 5

RATA-RATA $N$-GAIN TERNORMALISASI HASIL BELAJAR KELAS EKSPERIMEN DAN KONTROL

Kelas Uji Rata-rata N-Gain Kategori

\begin{tabular}{ccccc}
\hline \multirow{2}{*}{ Eksperimen } & Pretest & 71,55 & & \\
& Posttest & 85,51 & & \\
& Pretest & 71,42 & & \\
Kontrol & Posttest & 80,17 & 0,30 & Rendah \\
& & & & \\
\hline
\end{tabular}

Peningkatan untuk kelas eksperimen sebesar 0,49 atau peningkatannya sedang. Sedangkan di kelas kontrol dimana kelas yang diberi media 
pembelajaran presentasi juga mengalami peningkatan tetapi dalam kategori rendah

\section{Analisis Lembar Pendapat Siswa}

Dari hasil analisis pendapat siswa disebutkan bahwa aplikasi game edukasi berbasis platform game membantu siswa dalam belajar aljabar. Desain tampilan dan permainan menarik bagi siswa sehingga tidak membosankan, serta materi yang terdapat membantu siswa memahami konsep dan penyelesaian aljabar. Materi yang disusun di dalam aplikasi diberikan secara urut dan rinci dapat berjalan secara terstruktur dan sesuai tahapan pemahaman dan Kurikulum 2013. Tantangantantangan berisi tentang latihan soal menarik bagi siswa karena langsung dapat dikoreksi hasil jawaban benar maupun salah dengan tambahan konsekuensi dari pemilihan jawaban yang akan berpengaruh pada permainan. Secara keseluruhan aplikasi game edukasi berbasis platform game mendapat respons positif dari siswa dan sangat layak digunakan sebagai media pembelajaran aljabar.

\section{SIMPULAN DAN SARAN}

Proses pengembangan game edukasi berbasis Platform Game menggunakan software Construct 2 dengan hasil produk berupa game yang dimainkan pada komputer. Game edukasi berbasis platform game telah melalui proses validasi dari aspek tampilan maupun aspek materi oleh ahli media dan ahli materi. Berdasarkan hasil validasi diperoleh persentase kevalidan aspek media sebesar 75\% termasuk dalam kategori layak dan aspek materi sebesar $84,21 \%$ yang termasuk dalam kategori sangat layak. Setelah uji validitas media dan materi, produk diujikan dalam kelas skala kecil dengan perolehan presentase $86,3 \%$ dengan kategori sangat layak.

Kepraktisan game edukasi berbasis platform game diperoleh berdasarkan hasil analisis lembar instrumen kepraktisan pada uji skala besar yang memperoleh persentase sebesar $84,44 \%$ yang termasuk dalam kategori sangat layak. Media pembelajaran game edukasi memberikan dampak terhadap hasil belajar siswa, dengan berdasar pada uji Mann-Whitney diperoleh nilai signifikan $0,000<0,05$. Hal ini menneujukkan bahwa terdapat perbedaan rerata sebelum dan sesudah diberi media pembelajaran game edukasi berbasis platform game. Selain itu, berdasarkan uji N-Gain diperoleh nilai 4,90 yang berarti terjadi peningkatan sedang dari nilai pretest dan posttest siswa. Siswa menyatakan bahwa aplikasi tersebut menarik, tidak membosankan, dan dapat membantu dalam belajar khususnya materi aljabar. Kesimpulan yang dapat diambil berdasarkan hasil tersebut adalah game edukasi berbasis platform game pada materi aljabar sangat layak digunakan sebagai media pembelajaran dan dapat dikembangkan untuk materi lainnya.

\section{REFERENSI}

[1] Adiwijaya, Mohamad, Kodrat Imam S Dan Yuli Christyono. (2015). Perancangan Game Edukasi Platform Belajar Matematika Berbasis Android Menggunakan Construct 2. Semarang: Jurnal Transient Universitas Diponegoro Semarang, 4(1), 128-133

[2] Miarso, Yusufhadi. (2004). Menyemai Benih Teknologi Pendidikan. Jakarta: Kencana.

[3] Samani, Muchlas. (2007). Menggagas Pendidikan Bermakna: Integrasi Life Skill-KBK-CTL-MBS. Surabaya: Penerbit SIC.

[4] Sholikhin, Miftachus dan Kemal Farouq M. (2012). Game Pazz-Puzz Dengan Construt 2. Lamongan: Jurnal Teknika Universitas Islam Lamongan, 6(1)

[5] Sudrajat, Akhmad. (2008). Media Pembelajaran.(online).

(http://akhmadsudrajat.wordpress.com/2008/0 1/12/konsep-mediapembelajaran/), diakses tanggal 10 januari 2018 pukul 18.30

[6] Thomas, Drew. (2014). Creating a Mathematics Game Using Construct 2. Victoria: The Journal of Digital Learning and Teaching Victoria. 1(1), 7779 